\title{
PENAMBAHAN ENZIM FITASE PADA PAKAN BUATAN TERHADAP NILAI KECERNAAN PROTEIN DAN ENERGI IKAN BAUNG (Mystus nemurus) DENGAN TEKNIK PEMBEDAHAN
}

\author{
The Addition of Phytase Enzyme of Artificial Feed on the Digestibility Values Protein \\ and Energy Baung Fish (Mystus nemurus) with the Techniques of Surgery
}

\author{
Aprillia Mawaddah Rochmawati ${ }^{1 *}$, Muhammad Arief ${ }^{2}$ dan Prayogo $^{2}$ \\ ${ }^{1}$ Program Studi Budidaya Perairan, Fakultas Perikanan dan Kelautan, Universitas Airlangga, Surabaya \\ ${ }^{2}$ Departemen Manajemen Kesehatan Ikan dan Budidaya Perairan, Fakultas Perikanan dan Kelautan, Universitas \\ Airlangga, Surabaya \\ *aprilliamawaddah15@yahoo.com
}

\begin{abstract}
Abstrak
Ikan baung (Mystus nemurus) merupakan komoditas air tawar asli Indonesia yang memiliki nilai ekonomis tinggi. Kendala yang dihadapi dalam usaha pengembangan pakan buatan ikan baung untuk benih adalah pemanfaatan protein nabati dalam pakan belum optimal. Bahan-bahan nabati seperti tepung bungkil kedelai, jagung dan dedak padi. Kelompok tumbuhan dalam bentuk biji-bijian seperti padi, kacang-kacangan dan kelapa di dalamnya terdapat asam fitat. Asam fitat dapat bereaksi membentuk senyawa komplek dengan kalsium, magnesium, tembaga, seng, karbohidrat dan protein sehingga dapat mengurangi kecernaan nutrien tersebut. Salah satu enzim eksonegus pemecah asam fitat adalah enzim fitase. Fitase adalah enzim yang mampu menghidrolisa asam fitat menjadi inositol dan asam fosfat. Inositol merupakan salah satu vitamin yang diperlukan untuk pertumbuhan normal tubuh, pemeliharaan dan reproduksi. Asam fosfat berperan dalam aktivitas metabolisme dalam tubuh. Penelitian ini bertujuan untuk meningkatkan nilai kecernaan protein dan energi ikan baung. Penelitian ini dilaksanakan pada bulan April - Juni di Fakultas Perikanan dan Kelautan, Universitas Airlangga. Metode penelitian yang akan digunakan adalah metode eksperimental dengan rancangan acak lengkap. terdiri atas lima perlakuan dan empat kali ulangan. Parameter utama nilai kecernaan protein dan enegiikan baung yang diujikan di Laboratorium Pakan Ternak, Fakultas Kedokteran Hewan, Universitas Airlangga. Parameter pendukung yang diamati yaitu kualitas air pemeliharaan ikan baung. Penambahan enzim fitase pada dosis $450 \mathrm{mg}$ dapat meningkatkan nilai kecernaan protein dengan rata-rata 97,18\% - 97,86\%. Penambahan enzim fitase pada dosis $450 \mathrm{mg}$ dapat menaikkan kecernaan energi dengan rata-rata 96,97\% $97,99 \%$.
\end{abstract}

Kata Kunci: Asam Fitat, Enzim Fitase, Nilai Kecernaan Protein, Nilai Kecernaan Energi

\begin{abstract}
Baung fish (Mystus nemurus) is an Indonesian native freshwater commodities that have high economic value. Obstacles encountered in the effort to develop artificial feed fish baung for seeds is the utilization of vegetable protein in the diet is not optimal. Vegetable ingredients such as flour soybean meal, corn and rice bran. Groups of plants in the form of grains such as rice, beans and oil in it there is phytic acid. Phytic acid can react to form complex compounds with calcium, magnesium, copper, zinc, carbohydrates and proteins so as to reduce the nutrient digestibility. One enzyme breaker eksonegus phytic acid is the enzyme phytase. Phytase is an enzyme capable of hydrolyzing phytic acid into inositol and phosphoric acid. Inositol is a vitamin that is necessary for normal body growth, maintenance and reproduction. Phosphoric acid plays a role in metabolic activity in the body. This research aims to improve the digestibility of protein and energy value of baung fish. This research was conducted in April-June in the Faculty of Fisheries and Marine University Airlangga. Research method used in the study wasan experimental method with complete random planning. It included five treatments and four repetitions. The main parameter digestibility value protein and energy baung fish tested in the Laboratory Animal Feed, Faculty of Veterinary Medicine, University of Airlangga. Supporting parameters observed were water quality baung fish farming. The addition of the enzyme phytase at a dose of $450 \mathrm{mg}$ can increase digestibility values protein by an average of $97,18 \%-97,86 \%$. The addition of the enzyme phytase at a dose of $450 \mathrm{mg}$ could raise the digestibility values energy by an average of $96,97 \%-97,99 \%$.
\end{abstract}

Keywords: Phytic Acid, Phytase Enzyme, Digestibility Values Protein, Digestibility Values Energy 


\section{PENDAHULUAN}

Ikan baung (Mystus nemurus) merupakan komoditas air tawar asli Indonesia yang memiliki nilai ekonomis tinggi, baik sebagai ikan konsumsi maupun ikan hias (Akbar dan Agussyarif, 2013). Kendala yang dihadapi dalam usaha pengembangan pakan buatan ikan baung untuk benih adalah pemanfaatan protein nabati dalam pakan belum optimal. Bahan-bahan nabati seperti tepung bungkil kedelai, jagung dan dedak padi. Kelompok tumbuhan dalam bentuk biji-bijian seperti padi, kacangkacangan, dan kelapa di dalamnya terdapat asam fitat. Asam fitat pada $\mathrm{pH} \mathrm{7,4} \mathrm{akan}$ membuat komplek dengan mineral $\mathrm{Cu}^{2+}$, $\mathrm{Zn}^{2+}, \mathrm{Co}^{2+}, \mathrm{Mn}^{2+}, \mathrm{Fe}^{2+}, \mathrm{Ca}^{2+}$ dan membentuk garam yang mengendap, sehingga penyerapan nutrisi oleh darah terganggu (Rachmawati dan Istiyanto, 2014).

Asam fitat dapat bereaksi membentuk senyawa komplek dengan kalsium, magnesium, tembaga, seng, karbohidrat dan protein sehingga dapat mengurangi kecernaan nutrien tersebut (Suprayudi dkk, 2012). Salah satu enzim eksonegus pemecah asam fitat adalah enzim fitase. Fitase adalah enzim yang mampu menghidrolisa asam fitat menjadi inositol dan asam fosfat. Inositol merupakan salah satu vitamin yang diperlukan untuk pertumbuhan normal tubuh, pemeliharaan dan reproduksi (Rachmawati dan Istiyanto, 2014).

\section{METODOLOGI}

\section{Waktu dan Tempat}

Penelitian pakan dilaksanakan di Laboratorium Pendidikan Fakultas Perikanan dan Kelautan dan pengujian proksimat pakan di Laboratorium Pakan Fakultas Kedokteran Hewan, Universitas Airlangga pada bulan April sampai Juni 2016.

\section{Materi Penelitian}

Peralatan Penelitian

Alat-alat yang digunakan antara lain, akuarium sebanyak 20 buah dengan ukuran panjang $\mathrm{x}$ lebar $\mathrm{x}$ tinggi $(50 \mathrm{x} 30 \mathrm{x}$ $30 \mathrm{~cm}^{3}$ ), bak plastik, selang aerasi, batu aerasi, seser, timbangan digital, $\mathrm{pH}$ paper, ammonia tes kit, DO tes kit, termometer, gunting bedah, kertas saring, dan botol penyimpanan feses.

\section{Bahan Penelitian}

Bahan-bahan yang digunakan pada penelitian ini adalah menggunakan ikan baung (Mystus nemurus) dengan ukuran panjang $8-10 \mathrm{~cm}$ yang berasal dari Balai Benih Ikan Air Tawar Sukabumi, Jawa Barat. Ikan baung yang dibutuhkan sejumlah 200 ekor ikan, dengan perhitungan dalam satu akuarium terdapat 10 ekor ikan. Pakan yang digunakan adalah pakan buatan ransum berbentuk pelet. Bahan yang digunakan untuk pembuatan pakan pelet antara lain bungkil kedelai, tepung ikan, tepung jagung, dedak padi dan minyak ikan. Pakan uji ditambahkan enzim fitase dari merk Sunphase G.

\section{Metode Penelitian}

Metode penelitian yang digunakan untuk memecahkan suatu masalah yang dapat dilakukan dengan pengumpulan data melalui pengamatan, survei, ataupun melalui percobaan (Kusriningrum, 2011). Penelitian ini menggunakan metode eksperimental atau dengan lima perlakuan.

\section{Prosedur Kerja}

\section{Persiapan Pemeliharaan Ikan Baung (Mystus nemurus)}

Tahap awal dalam melakukan persiapan yaitu menyiapkan akuarium yang akan digunakan dengan ukuran 50x30x30 $\mathrm{cm}^{3}$. Ikan baung sebanyak 200 ekor yang telah diukur panjang dan berat tubuhnya ditebar ke dalam akuarium dengan kepadatan 10 ekor/akuarium serta diberi aerasi.

\section{Penyediaan Pakan Ikan Baung (Mystus nemurus)}

Pakan yang diberikan untuk ikan baung berupa pakan buatan yang ditambahkan enzim fitase. Semua bahan-bahan penyusun pakan disiapkan dan ditimbang sesuai kebutuhan yang ditentukan. Percampuran bahan dilakukan secara ber- 
tahap, mulai dari jumlah presentasenya kecil hingga presentase yang besar agar campuran menjadi homogen. Penambahan enzim fitase dibedakan berdasarkan tiap perlakuan. Adonan dicetak dan dikering- kan di bawah sinar matahari. Pelet yang telah dikeringkan kemudian dianalisis kadar proksimatnya. Komposisi nutrisi pakan ikan baung pada perlakuan Tabel 1 .

Tabel 1. Komposisi Nutrisi Pakan Ikan Baung Perlakuan

\begin{tabular}{lccccc}
\multicolumn{1}{c}{ Bahan } & $\mathbf{0}$ & $\mathbf{1}$ & $\mathbf{2}$ & $\mathbf{3}$ & $\mathbf{4}$ \\
\hline Tepung Ikan & 45 & 45 & 45 & 45 & 45 \\
Bungkil Kedelai & 37 & 37 & 37 & 37 & 37 \\
Tepung Jagung & 8 & 8 & 8 & 8 & 8 \\
Dedak Padi & 5.6 & 5.6 & 5.6 & 5.6 & 5.6 \\
Tepung Tapioka & 1 & 1 & 1 & 1 & 1 \\
Mineral Mix & 0.2 & 0.2 & 0.2 & 0.2 & 0.2 \\
Minyak Ikan & 0.2 & 0.2 & 0.2 & 0.2 & 0.2 \\
Molase & 3 & 3 & 3 & 3 & 3 \\
Enzim Fitase & 0 & 0.045 & 0.05 & 0.055 & 0.06 \\
Total (\%) & 100 & 100.045 & 100.05 & 100.055 & 100.06 \\
BK (\%) & 85.4765 & 85.4765 & 85.4765 & 85.4765 & 85.4765 \\
Abu (\%) & 11.0886 & 11.0886 & 11.0886 & 11.0886 & 11.0886 \\
Protein (\%) & 37.1952 & 37.1952 & 37.1952 & 37.1952 & 37.1952 \\
Lemak (\%) & 9.1559 & 9.1559 & 9.1559 & 9.1559 & 9.1559 \\
Serat (\%) & 13.3502 & 13.3502 & 13.3502 & 13.3502 & 13.3502 \\
BETN (\%) & 17.3087 & 17.3087 & 17.3087 & 17.3087 & 17.3087 \\
ME (kkal/kg) & 3634.444 & 3634.444 & 3634.444 & 3634.444 & 3634.444 \\
C/P (kkal/kg) & 9.7713 & 9.7713 & 9.7713 & 9.7713 & 9.7713 \\
Harga (Rp) & 8661 & 8697 & 8701 & 8705 & 8709 \\
\hline
\end{tabular}

Pemberian Pakan Ikan Baung (Mystus nemurus)

Pengaturan pakan diberikan dengan berat $3 \%$ dari total biomasa pemberian pakan sebanyak tiga kali dalam sehari yaitu pukul 08.00,13.00 dan 18.00 WIB.

\section{Parameter Penelitian}

Parameter utama dalam penelitian ini adalah nilai kecernaan protein dan energi dalam feses ikan baung yang diujikan di Laboratorium Pakan Ternak, Fakultas Kedokteran Hewan, Universitas Airlangga Suarabaya. Parameter pendukung yang diamati yaitu parameter kualitas air seperti, suhu, DO, pH dan amonia.

\section{Analisis Data}

Data yang diperoleh dianalisis dengan menggunakan uji statistik ANOVA (Analisis of Variance) untuk mengetahui apakah ada perbedaan antar perlakuan, kemudian dilanjutkan dengan Uji Jarak Berganda Duncan (Duncan's Multiple Range Test) dengan taraf nyata 5\% untuk mengetahui perlakuan yang terbaik (Kusriningrum, 2011).

\section{HASIL DAN PEMBAHASAN \\ Kecernaan Protein Ikan Baung}

Berdasarkan penelitian pada nilai kecernaan protein diperoleh hasil nilai kecernaan protein berkisar antara 97,18\%$97,86 \%$. Data rata-rata nilai kecernaan protein ikan baung dapat dilihat pada Tabel 2.

Hasil perhitungan analisis data Anava menunjukkan bahwa terdapat perbedaan yang nyata $(\mathrm{p}<0,05)$ terhadap angka dari nilai kecernaan protein ikan baung (Mystus nemurus). Selanjutnya setelah dilakukan uji jarak berganda Duncan 5\%

Diterima/submitted:3 September 2016 Disetujui/accepted:11 Desember 2016 
dapat dilihat bahwa perlakuan $\mathrm{P}_{0}$ berbeda nyata dengan perlakuan $\mathrm{P}_{2}, \mathrm{P}_{3}$ dan $\mathrm{P}_{4} . \mathrm{P}_{0}$ tidak berbeda nyata dengan $\mathrm{P}_{1}$ dan $\mathrm{P}_{1}$ juga tidak berbeda nyata dengan $\mathrm{P}_{2}, \mathrm{P}_{3}, \mathrm{P}_{4}$. Sehingga hasil rata-rata dari nilai kecernaan protein terbaik ditunjukkan pada perlakuan $\mathrm{P}_{2}$ yaitu sebesar $97,86 \%$. Nilai kecernaan protein terendah yaitu sebesar $97,18 \%$ yang terdapat pada perlakuan $\mathrm{P}_{0}$ tanpa penambahan enzim fitase pada pakan buatan, sedangkan jumlah nilai kecernaan protein tertinggi yaitu pada perlakuan $\mathrm{P}_{2}$ sebesar $97,86 \%$ dengan penambahan enzim fitase sebesar $500 \mathrm{mg}$.

Tabel 2. Rata-rata Nilai Kecernaan Protein Ikan Baung (Mystus nemurus)

\begin{tabular}{ccc}
\hline Perlakuan & Rata-rata Nilai Kecernaan $(\%) \pm$ SD & Transformasi $(\sqrt{\mathrm{y}}) \pm$ SD \\
\hline $\mathrm{P}_{0}$ & $97,18^{\mathrm{b}} \pm 0,35$ & $9,86 \pm 0,02$ \\
$\mathrm{P}_{1}$ & $97,41^{\mathrm{ab}} \pm 0,48$ & $9,87 \pm 0,02$ \\
$\mathrm{P}_{2}$ & $97,86^{\mathrm{a}} \pm 0,38$ & $9,89 \pm 0,02$ \\
$\mathrm{P}_{3}$ & $97,82^{\mathrm{a}} \pm 0,07$ & $9,89 \pm 0,004$ \\
$\mathrm{P}_{4}$ & $97,72^{\mathrm{a}} \pm 0,09$ & $9,89 \pm 0,01$
\end{tabular}

Keterangan : Superskrip yang berbeda pada kolom yang sama menunjukkan terdapat perbedaan yang nyata $(\mathrm{P}<0,05)$

Hasil perhitungan analisis data Anava menunjukkan bahwa terdapat perbedaan yang nyata $(\mathrm{p}<0,05)$ terhadap angka dari nilai kecernaan protein ikan baung (Mystus nemurus). Selanjutnya setelah dilakukan uji jarak berganda Duncan 5\% dapat dilihat bahwa perlakuan $\mathrm{P}_{0}$ berbeda nyata dengan perlakuan $\mathrm{P}_{2}, \mathrm{P}_{3}$ dan $\mathrm{P}_{4} . \mathrm{P}_{0}$ tidak berbeda nyata dengan $\mathrm{P}_{1}$ dan $\mathrm{P}_{1}$ juga tidak berbeda nyata dengan $\mathrm{P}_{2}, \mathrm{P}_{3}, \mathrm{P}_{4}$. Sehingga hasil rata-rata dari nilai kecernaan protein terbaik ditunjukkan pada perlakuan $\mathrm{P}_{2}$ yaitu sebesar $97,86 \%$. Nilai kecernaan protein terendah yaitu sebesar $97,18 \%$ yang terdapat pada perlakuan $\mathrm{P}_{0}$ tanpa penambahan enzim fitase pada pakan buatan, sedangkan jumlah nilai kecernaan protein tertinggi yaitu pada perlakuan $\mathrm{P}_{2}$ sebesar $97,86 \%$ dengan penambahan enzim fitase sebesar $500 \mathrm{mg}$.

Nilai rata-rata kecernaan protein tertinggi terdapat pada perlakuan $\mathrm{P}_{2}$ sebesar $(97,86 \%)$. Hal ini menunjukkan bahwa pemberian pakan dengan kadar protein 0.310701 gram yang telah ditambah enzim fitase $(500 \mathrm{mg})$ dapat memberikan nilai kecernaan protein sebesar $(97,86 \%)$. Hal ini dapat diartikan bahwa setiap 0.310701 gram protein pakan yang dikonsumsi, dapat dicerna oleh tubuh ikan baung sebesar $(97,86 \%$ x 0.310701 gram $)$ atau 0,304 gram. Nilai tertinggi didapatkan pada $\mathrm{P}_{2}$ (dosis enzim fitase $500 \mathrm{mg}$ ) dan terendah pada $\mathrm{P}_{0}$ (tanpa penambahan enzim fitase), hal ini diduga karena adanya penambahan enzim fitase dengan dosis yang tepat yaitu $500 \mathrm{mg}$ mampu memecah asam fitat dalam pakan sehingga protein dapat dimanfaatkan secara maksimal dan enzim fitase dalam pakan yang mampu menurunkan dan menguraikan asam fitat serta memutuskan ikatan antara asam fitat dengan protein dan mineral kompleks, sehingga akan memberikan pengaruh terhadap enzim-enzim pencernaan khususnya enzim pemecah protein dalam menguraikan protein menjadi asam amino (Rachmawati dan Istiyanto, 2014). Hidrolisis protein yang sempurna akan menghasilkan asam amino yang semakin tinggi, sehingga semakin banyak yang diserap oleh tubuh (Winarno, 1995). Dosis terbaik dalam penelitian kecernaan protein ini adalah $\mathrm{P}_{1}$ (dosis enzim fitase $450 \mathrm{mg}$ ) karena dengan dosis enzim fitase terendah sudah dapat menghidrolisis asam fitat yang dapat meningkatkan nilai kecernaan protein dan pakan tersebut memiliki nilai ekonomis dibandingkan 
dengan perlakuan lainnya.

Menurut Rachmawati dan Istiyanto (2014), enzim fitase berfungsi untuk menaikkan penyerapan nutrien dan mengatur ekskresi nutrien (fosfor, nitrogen dan mineral) dengan menghidrolisis asam fitat yang terdapat pada pakan buatan menjadi inositol dan asam fosfat. Aktifitas hidrolisis tersebut terjadi di dalam pakan, sehingga tubuh ikan dapat menyerap nutrisi dan mineral tersebut secara lebih maksimal. Pemberian dosis enzim fitase yang sesuai dibutuhkan agar proses hidrolisis tersebut dapat berjalan dengan baik. Jumlah dosis yang berlebihan dinilai tidak baik dikarenakan asam fitat yang terkandung dalam pakan banyak yang terurai. Hal ini juga dapat menyebabkan protein dan fosfor yang terikat pada asam fitat juga banyak yang terurai, sehingga kecernaan protein ikan baung menjadi menurun.

\section{Kecernaan Energi Ikan Baung}

Berdasarkan penelitian pada nilai kecernaan energi diperoleh hasil nilai kecernaan protein berkisar antara 96,97\%$97,99 \%$. Data rata-rata nilai kecernaan energi ikan baung dapat dilihat pada Tabel 3.

Tabel 3. Rata-rata Nilai Kecernaan Energi Ikan Baung (Mystus nemurus)

\begin{tabular}{ccc}
\hline Perlakuan & Rata-rata Nilai Kecernaan $(\%) \pm \mathbf{S D}$ & Transformasi $(\sqrt{\mathbf{y}}) \pm \mathbf{S D}$ \\
\hline $\mathrm{P}_{0}$ & $96,97^{\mathrm{b}} \pm 0,54$ & $9,85 \pm 0,03$ \\
$\mathrm{P}_{1}$ & $97,57^{\mathrm{ab}} \pm 0,42$ & $9,88 \pm 0,02$ \\
$\mathrm{P}_{2}$ & $97,99^{\mathrm{a}} \pm 0,52$ & $9,9 \pm 0,03$ \\
$\mathrm{P}_{3}$ & $97,73^{\mathrm{a}} \pm 0,25$ & $9,89 \pm 0,01$ \\
$\mathrm{P}_{4}$ & $97,5^{\mathrm{ab}} \pm 0,11$ & $9,88 \pm 0,01$ \\
\hline
\end{tabular}

Keterangan : Superskrip yang berbeda pada kolom yang sama menunjukkan terdapat perbedaan yang nyata $(\mathrm{P}<0,05)$

Hasil perhitungan analisis data Anava menunjukkan bahwa terdapat perbedaan yang nyata $(\mathrm{p}<0,05)$ terhadap angka dari nilai kecernaan energi ikan baung (Mystus nemurus). Selanjutnya setelah dilakukan uji jarak berganda Duncan 5\% dapat dilihat bahwa perlakuan $\mathrm{P}_{0}$ berbeda nyata dengan perlakuan $\mathrm{P}_{2}$, dan $\mathrm{P}_{3}$. $\mathrm{P}_{0}$ tidak berbeda nyata dengan $\mathrm{P}_{1}$ dan $\mathrm{P}_{4} \mathrm{P}_{1}$ dan $\mathrm{P}_{4}$ juga tidak berbeda nyata dengan $\mathrm{P}_{2}$ dan $\mathrm{P}_{3}$, sehingga hasil rata-rata dari nilai kecernaan energi terbaik ditunjukkan pada perlakuan $\mathrm{P}_{2}$ yaitu sebesar $97,99 \%$. Nilai kecernaan energi terendah yaitu sebesar 96,97\% yang terdapat pada perlakuan $\mathrm{P}_{0}$ tanpa penambahan enzim fitase pada pakan buatan, sedangkan jumlah nilai kecernaan energi tertinggi yaitu pada perlakuan $\mathrm{P}_{2}$ sebesar $97,99 \%$ dengan penambahan enzim fitase sebesar $500 \mathrm{mg}$.

Nilai rata-rata kecernaan energi ter- tinggi terdapat pada perlakuan $\mathrm{P}_{2}$ sebesar $(97,99 \%)$. Hal ini menunjukkan bahwa pemberian pakan dengan kadar energi $3,0123975 \mathrm{kcal} / \mathrm{g}$ yang telah ditambah enzim fitase $(500 \mathrm{mg}$ ) dapat memberikan nilai kecernaan energi sebesar $(97,99 \%)$. Hal ini dapat diartikan bahwa setiap 3,012975 kcal/g energi pakan yang dikonsumsi, dapat dicerna oleh tubuh ikan baung sebesar $(97,99 \%$ x 3,012975 kcal/g) atau 2,951848 $\mathrm{kcal} / \mathrm{g}$. Nilai tertinggi didapatkan pada $\mathrm{P}_{2}$ (dosis enzim fitase 500 $\mathrm{mg}$ ) dan terendah pada $\mathrm{P}_{0}$ (tanpa penambahan enzim fitase), hal ini diduga karena adanya penambahan enzim fitase dengan dosis yang tepat yaitu $500 \mathrm{mg}$ mampu memecah asam fitat dalam pakan. Dosis terbaik dalam penelitian kecernaan energi ini adalah $\mathrm{P}_{1}$ (dosis enzim fitase $450 \mathrm{mg}$ ) karena dengan dosis enzim fitase terendah sudah dapat menghidrolisis asam fitat yang 
dapat meningkatkan nilai kecernaan energi dan pakan tersebut memiliki nilai ekonomis dibandingkan dengan perlakuan lainnya. Enzim fitase dalam pakan yang mampu menurunkan dan menguraikan asam fitat serta memutuskan ikatan antara asam fitat dengan protein, lemak dan karbohidrat sehingga akan memberikan pengaruh terhadap enzim-enzim pencernaan yang dapat meningkatkan kecernaan energi. Aktifitas hidrolisis tersebut terjadi di dalam pakan, sehingga tubuh ikan dapat menyerap nutrisi dan mineral tersebut secara lebih maksimal. Pemberian dosis enzim fitase yang sesuai dibutuhkan agar proses hidrolisis tersebut dapat berjalan dengan baik. Jumlah dosis yang berlebihan dinilai tidak baik dikarenakan asam fitat yang terkandung dalam pakan banyak yang terurai, sehingga kecernaan energi ikan baung menjadi menurun (Rachmawati dan Istyanto, 2014).

\section{Kualitas Air pada Pemeliharaan Ikan Baung (Mystus nemurus)}

Nilai kisaran kualitas air pada pemeliharaan ikan baung sebagai berikut : suhu antara $26-27^{\circ} \mathrm{C}, \mathrm{pH} 7-8$, oksigen terlarut $6-8 \mathrm{mg} / \mathrm{l}$ dan amonia $0-0,10 \mathrm{mg} / \mathrm{l}$. Hasil pengukuran kualitas air pemeliharaan ikan dapat dilihat pada Tabel 4.

Tabel 4. Hasil pengukuran kualitas air pemeliharaan ikan baung (Mystus nemurus)

\begin{tabular}{clcc}
\hline No & \multicolumn{1}{c}{ Parameter } & Satuan & Kisaran \\
\hline 1 & Suhu & ${ }^{\circ} \mathrm{C}$ & $26-27$ \\
2 & Oksigen terlarut (DO) & $\mathrm{mg} / \mathrm{l}$ & $6-8$ \\
3 & $\mathrm{pH}$ & - & $7-8$ \\
4 & Amonia & $\mathrm{mg} / \mathrm{l}$ & $0-0,10$ \\
\hline
\end{tabular}

Kualitas air yang diukur mencakup suhu, $\mathrm{pH}$, oksigen terlarut, dan amonia. Suhu yang merupakan salah satu faktor lingkungan pada saat pemeliharaan ikan berlangsung berkisar antara $26-27^{\circ} \mathrm{C}$. Menurut Khairuman dan Amri (2010) Kisaran suhu air ideal bagi ikan baung adalah $25^{\circ}-32^{\circ} \mathrm{C}$, sehingga dengan suhu $26-27^{\circ} \mathrm{C}$ tidak memberikan pengaruh terhadap nilai kecernaan protein dan energi. Faktor kimia lingkungan salah satunya adalah $\mathrm{pH}$. Nilai $\mathrm{pH}$ selama masa pemeliharaan adalah 7-8. Menurut Khairuman dan Amri (2010) nilai kisaran $\mathrm{pH}$ air ideal untuk budidaya ikan baung antara 6,5-8. Oksigen terlarut selama masa pemeliharaan adalah 6-8 $\mathrm{mg} / \mathrm{l}$.

Menurut Suhenda (2010) oksigen terlarut yang baik untuk budidaya ikan baung berkisar 3-8 mg/l. Amonia pada masa pemeliharaan memiliki nilai $0-0,10$ mg/l. Boyd (1979) mengatakan bahwa tingkatan racun $\mathrm{NH}_{3}$ untuk jangka pendek berada diantara 0,6-2,0 mg/l. Menurut Effendi (2000) kandungan amonia pada perairan tawar tidak melebihi $0,2 \mathrm{mg} / \mathrm{l}$ karena jika melebihi kadar tersebut dapat menyebabkan toksik bagi beberapa jenis ikan. Berdasarkan data yang diuraikan diatas, kualitas air tidak berpengaruh pada kecernaan protein dan energi karena telah sesuai dengan standar kualitas air dalam budidaya ikan.

\section{KESIMPULAN DAN SARAN Kesimpulan}

Berdasarkan hasil penelitian ini diperoleh kesimpulan bahwa penambahan enzim fitase pada pakan buatan ikan baung (Mystus nemurus) dengan dosis $450 \mathrm{mg}$ dapat meningkatkan nilai kecernaan protein dan energi.

\section{Saran}

Berdasarkan hasil penelitian, untuk dapat menaikkan nilai kecernaan protein dan energi pada ikan baung perlu ditambahkan enzim fitase dengan dosis $500 \mathrm{mg}$ yang merupakan dosis tertinggi. Sedangkan dosis terbaik secara ekonomis untuk dapat menaikkan nilai kecernaan tersebut yaitu sebesar $450 \mathrm{mg}$.

Diterima/submitted:3 September 2016 Disetujui/accepted:11 Desember 2016 


\section{DAFTAR PUSTAKA}

Akbar, J dan Agussyarif, H. 2013. Efek Pemberian Dosis Akriflavin dan Lama Perendaman yang Berbeda terhadap Rasio Pembentukan Kelamin Jantan Ikan Baung (Hemibagrus nemurus). Universitas Lambung Mangkurat. Kalimantan Selatan. 2(1) : 1-5.

Boyd, E. C., dan F. Lichkoppler. 1979. Water Quality Management in Pond Fish Culture / Pengelolaan Kualitas Air Kolam. Alih Bahasa : Artati, F. Cholik, dan R. Arifudin. 1986. Dirjen Perikanan, Jakarta. 52 hlm.

Effendi, H. 2000. Telaahan Kualitas Air Bagi Pengelolaan Sumberdaya Dan Lingkungan Perairan. Kanisius. Yogyakarta.

Khairuman.K. Amri. 2010. Ikan baung, peluang usaha dan teknik budidaya intensif. PT. Gramedia Pustaka Utama, Jakarta. 88 hal.

Kusriningrum. 2011. Perancangan Percobaan. Fakultas Kedokteran Hewan Universitas Airlangga. Surabaya.

Rachmawati, D., dan Istiyanto, S. 2014. Penambahan Fitase dalam Pakan Buatan sebagai Upaya Peningkatan Kecernaan, Laju Pertumbuhan Spesifik dan Kelulushidupan Benih Ikan Nila (Oreochromis niloticus). Jurnal Saintek Perikanan. 10(1) : 48-55.

Suhenda, N. 2010. Penentuan Awal Pemberian Pakan untuk Mendukung Sintasan dan Pertumbuhan Larva Ikan Baung (Hemibagrus nemurus). Balai Riset Perikanan Budidaya Air Tawar. Bogor.

Suprayudi, M. A. Dini, H dan Dedi, J. 2012. Kecernaan Pakan dan Pertumbuhan Udang Putih Litopenaeus vannamei Diberi Pakan Mengandung Enzim Fitase Berbeda. Institut Pertanian Bogor. Jurnal akuakultur Indonesia 11 (2) : 103-108.
Winarno, F.G. 1995. Pengantar Teknologi Pangan. PT. Gramedia Pustaka Utama. Jakarta. 108 hlm.

Diterima/submitted:3 September 2016

Disetujui/accepted:11 Desember 2016 